\title{
CdS/ZnS/ZnO ternary heterostructure nanofibers fabricated by electrospinning for excellent photocatalytic hydrogen evolution without co-catalyst
}

\author{
Diankun Sun, Jian-Wen Shi *, Dandan Ma, Yajun Zou, Guotai Sun, Siman Mao, Lvwei Sun, \\ Yonghong Cheng
}

State Key Laboratory of Electrical Insulation and Power Equipment, Center of Nanomaterials for Renewable Energy, School of Electrical Engineering, Xi'an Jiaotong University, Xi'an 710049, Shaanxi, China

\section{A R T I C L E I N F O}

\section{Article history:}

Received 18 January 2020

Accepted 24 February 2020

Published 5 September 2020

\section{Keywords:}

Photocatalysis

$\mathrm{H}_{2}$ evolution

Water splitting

Electrospinning

Heterostructure

\begin{abstract}
A B S T R A C T
In recent years, ternary heterostructures (HSs) composed of three semiconductors have attracted significant attention because of the effective separation and transfer of photogenerated electrons and holes in these materials. In this work, new ternary CdS/ZnS/ZnO (CZZ) HSs with one-dimensional (1D) nanofiber morphology have been successfully fabricated for the first time by a series of processes: electrospinning $\mathrm{ZnO}$ nanofibers, sulfurizing $\mathrm{ZnO}$ in situ to form $\mathrm{ZnS} / \mathrm{ZnO}$ binary HSs, and depositing CdS quantum dots in situ on the ZnS/ZnO HSs. Benefiting from the efficient separation and transfer of photoinduced charge carriers, the optimized CZZ ternary HSs exhibit a hydrogen evolution rate of $51.45 \mathrm{mmol} \mathrm{h}^{-1} \mathrm{~g}^{-1}$ (quantum efficiency: $26.88 \%$ at $420 \mathrm{~nm}$ ) without any co-catalyst, which is 93.54 and 2.28 times higher than those exhibited by pristine $\mathrm{ZnO}$ and $\mathrm{ZnS} / \mathrm{ZnO}$ binary HSs, respectively, under the same conditions. Furthermore, the rate of hydrogen evolution over the 1D CZZ nanofibers is significantly higher than that over 2D CZZ nanosheets $(27.25 \mathrm{mmol}$ $\mathrm{h}^{-1} \mathrm{~g}^{-1}$, in the presence of a Pt co-catalyst) prepared by the same sulfurization and deposition procedures. This can be ascribed to the significantly smaller geometric sizes of 1D nanofibers compared to those of 2D nanosheets, resulting in effectively suppressed recombination of photogenerated charge carriers and promotion of photocatalytic $\mathrm{H}_{2}$ evolution performance.
\end{abstract}

(C) 2020, Dalian Institute of Chemical Physics, Chinese Academy of Sciences. Published by Elsevier B.V. All rights reserved.

\section{Introduction}

Environmental and energy issues are the two major factors hindering the sustainable development of human society. Photocatalysis is considered one of the effective routes to solve the above two issues [1-7]. Since the pioneering work of Fujishima and Honda in 1972 [8] on photoelectrochemical water splitting over a $\mathrm{TiO}_{2}$ electrode, photocatalytic $\mathrm{H}_{2}$ generation has been investigated as one of the most promising routes to convert solar energy into available chemical energy [9-15]. Until now, many semiconductors, such as $\mathrm{TiO}_{2}$ [16-18], g- $\mathrm{C}_{3} \mathrm{~N}_{4}$ [19-22], $\mathrm{ZnO}[23,24]$, and CdS [25,26], have been explored as photocatalysts for hydrogen generation by water splitting. However, single semiconductors have some disadvantages such as high recombination probability of photocarriers and limited redox potential [27-29].

Heterostructures (HSs) consisting of two or more semiconductors have the following advantages. First, the bandgaps of

\footnotetext{
*Corresponding author. Tel/Fax: +86-29-83395372; E-mail: jianwen.shi@mail.xjtu.edu.cn

This work was sponsored by the National Natural Science Foundation of China (21972110), the Natural Science Foundation of Shaanxi Province, China (2019JM-154), and the State Key Laboratory of Electrical Insulation and Power Equipment, China (EIPE19123).

DOI: 10.1016/S1872-2067(20)63576-8 | http://www.sciencedirect.com/science/iournal/18722067 | Chin. I. Catal., Vol. 41, No. 9, September 2020
} 
HSs can be easily adjusted by introducing guest semiconductors with suitable bandgap positions. This helps in expanding the light absorption region of the photocatalyst and improving the utilization efficiency of solar energy [30,31]. Second, HSs provide abundant active interfaces for the photocatalytic process; moreover, the heterojunctions in HSs promote the separation and transfer of photogenerated electrons and holes [32-34].

Binary semiconductor HSs with three different configurations: type-I [35], type-II [36,37], and Z-scheme [38] have been reported. In recent years, ternary HSs consisting of three semiconductors have attracted considerable attention. For example, Xie et al. [39] prepared new ternary $\mathrm{ZnTiO}_{3} / \mathrm{Zn}_{2} \mathrm{Ti}_{3} \mathrm{O}_{8} / \mathrm{ZnO} \mathrm{HSs}$ with high efficiency for photocatalytic hydrogen evolution and polluted water treatment. Jang et al. [40] fabricated ternary $\mathrm{CdS} / \mathrm{ZnIn}_{2} \mathrm{~S}_{4} / \mathrm{TiO}_{2}$ HSs with excellent photoelectrochemical performance. In our previous study, we successfully synthesized a series of ternary $\mathrm{HSs}: \mathrm{MoO}_{3} / \mathrm{MoS}_{2} / \mathrm{g}-\mathrm{C}_{3} \mathrm{~N}_{4}$ [41], $\mathrm{CdS} / \mathrm{WS}_{2} / \mathrm{g}-\mathrm{C}_{3} \mathrm{~N}_{4} \quad$ [42], $\operatorname{In}_{2} \mathrm{~S}_{3} / \mathrm{CdIn}_{2} \mathrm{~S}_{4} / \mathrm{In}_{2} \mathrm{O}_{3} \quad$ [43], and $\mathrm{CdS} / \mathrm{ZnS} / \mathrm{PdS}$ [44]. These ternary HSs exhibited enhanced photocatalytic $\mathrm{H}_{2}$ evolution performances compared to the corresponding binary HSs and single semiconductors. Therefore, ternary HS-based materials are considered promising photocatalysts.

In our previous work [32], we fabricated new ternary $\mathrm{CdS} / \mathrm{ZnS} / \mathrm{ZnO}$ (abbreviated as CZZ) HSs by two steps. Firstly, $\mathrm{ZnO}$ nanosheets were sulfurized in situ to form $\mathrm{ZnS} / \mathrm{ZnO}$ binary HSs. Secondly, CdS quantum dots (QDs) were deposited in situ on the ZnS/ZnO HSs to obtain CZZ ternary HSs. The CZZ ternary HSs exhibited a hydrogen evolution rate of $27.25 \mathrm{mmol} \mathrm{h}^{-1} \mathrm{~g}^{-1}$ in the presence of a Pt co-catalyst. In order to further improve the photocatalytic performance of the CZZ ternary HSs, in the current work, we constructed new CZZ ternary HSs by the same procedure used in our previous work; however, the two-dimensional (2D) ZnO nanosheets were replaced with 1D $\mathrm{ZnO}$ nanofibers, which were prepared by electrospinning. The resultant CZZ nanofibers exhibited a much higher hydrogen evolution rate of $51.45 \mathrm{mmol} \mathrm{h}^{-1} \mathrm{~g}^{-1}$ without any co-catalyst. The reason for the enhancement in photocatalytic $\mathrm{H}_{2}$ evolution was analyzed in detail. Furthermore, these photocatalysts are economical because they are co-catalyst-free (noble metals, such as $\mathrm{Pt}$ and $\mathrm{Au}$, are the most widely used co-catalysts), thus making our study more significant.

\section{Experimental}

\subsection{Synthesis of photocatalysts}

\subsubsection{Synthesis of $\mathrm{ZnO}$ nanofibers}

$\mathrm{ZnO}$ nanofibers were synthesized by electrospinning. Firstly, $0.226 \mathrm{~g}$ of zinc acetate $\left[\mathrm{Zn}\left(\mathrm{CH}_{3} \mathrm{COO}\right)_{2}\right]$ was dissolved in 12 $\mathrm{mL}$ of $\mathrm{N}, \mathrm{N}$-dimethylformamide (DMF), and then, $4 \mathrm{~g}$ of polyvinylpyrrolidone (PVP) powder (molecular weight $=900000$ ) was added and stirred at room temperature for $6 \mathrm{~h}$ to obtain the $\mathrm{Zn}\left(\mathrm{CH}_{3} \mathrm{COO}\right)_{2}$-PVP precursor for electrospinning. Subsequently, the precursor was placed in an injector for electrospinning. The electrospinning device and procedure used were the same as those used in our previous study [45]. In this work, the supply voltage was $15 \mathrm{kV}$, distance between the steel needle and the aluminum foil was $10 \mathrm{~cm}$, speed of the syringe pump was $0.4 \mathrm{~mL} / \mathrm{h}$, and speed of the cylinder was $200 \mathrm{rpm}$. The electrospun $\mathrm{PVP} / \mathrm{Zn}\left(\mathrm{CH}_{3} \mathrm{COO}\right)_{2}$ composite nanofibers were calcined at $550{ }^{\circ} \mathrm{C}$ in air for $3 \mathrm{~h}$ at a heating rate of $1{ }^{\circ} \mathrm{C} / \mathrm{min}$ to obtain $\mathrm{ZnO}$ nanofibers.

\subsubsection{Synthesis of ZnS/ZnO binary heterostructures}

$\mathrm{ZnS} / \mathrm{ZnO}$ binary HSs were prepared by in situ sulfidation. Typically, $25 \mathrm{mg}$ of the prepared $\mathrm{ZnO}$ nanofibers were ultrasonically dispersed in aqueous thiourea solutions with three different concentrations obtained by dissolving 30,35 , and 40 mg of thiourea in $5 \mathrm{~mL}$ of water, respectively. The resultant suspensions were then heated at $150{ }^{\circ} \mathrm{C}$ for $45 \mathrm{~min}$ in a Teflon autoclave $(20 \mathrm{~mL})$ to achieve in situ sulfidation of $\mathrm{ZnO}$ nanofibers, yielding ZnS/ZnO binary HSs. The obtained ZnS/ZnO binary HSs were labeled as ZZ- $x$ ( $x$ stands for the weight of thiourea added).

\subsubsection{Synthesis of CdS/ZnS/ZnO ternary heterostructures}

$\mathrm{CdS} / \mathrm{ZnS} / \mathrm{ZnO}$ ternary HSs were synthesized by in situ deposition of CdS QDs on ZnS/ZnO binary HSs (ZZ-35) by the successive ionic layer adsorption and reaction method [46]. The amount of CdS QDs deposited was controlled by adjusting the number of deposition cycles. One deposition cycle involved the following steps. (1) The prepared ZnS/ZnO binary HSs were immersed in $0.1 \mathrm{~mol} / \mathrm{L} \mathrm{Cd}\left(\mathrm{CH}_{3} \mathrm{COO}\right)_{2}$ solution for $5 \mathrm{~min}$, and then, washed with deionized water to remove the excess $\mathrm{Cd}^{2+}$ ions. (2) The resulting sample was dried in air, immersed in 0.1 $\mathrm{mol} / \mathrm{L} \mathrm{Na}_{2} \mathrm{~S}$ solution for $5 \mathrm{~min}$, and finally, washed with deionized water. Accordingly, a series of CdS/ZnS/ZnO ternary HSs were obtained. The obtained CdS/ZnS/ZnO ternary HSs were denoted as CZZ-y ( $y$ stands for the number of deposition cycles). For comparison, a pristine CdS sample was synthesized according to the procedure described in our previous report [47]. The synthesis of CdS/ZnS/ZnO ternary HSs is illustrated in Scheme 1.

\subsection{Characterization}

X-ray diffraction (XRD) was performed with an X-ray diffraction system using the $\mathrm{Cu} K_{\alpha}$ radiation. Transmission electron microscopy (TEM) and high-resolution TEM (HRTEM) were performed with a JEOL JEM-2100F microscope at an op-

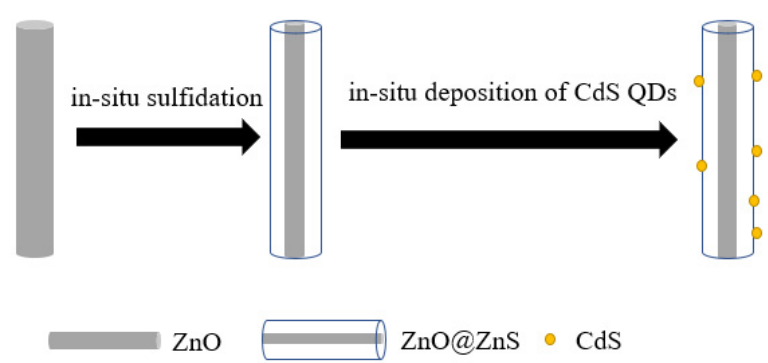

Scheme 1. Schematic illustration of ternary CdS/ZnS/ZnO HS synthesis. 
erating voltage of $200 \mathrm{kV}$. The morphology of the prepared catalysts was characterized by scanning electron microscopy (SEM, SU6600 Hitachi, Japan). The elemental compositions of the catalysts were determined with an energy-dispersive X-ray spectroscopy (EDX) system integrated into an SEM instrument (Phenom Prox). Ultraviolet-visible (UV-vis) absorption spectra were recorded with a V-670 spectrophotometer. X-ray photoelectron spectroscopy (XPS) was performed with a Thermo Fisher Scientific ESCALAB spectrometer using the aluminum $\mathrm{K}_{\alpha}$ radiation. The photoluminescence (PL) spectra were recorded on a fluorescence spectrometer (Edinburgh Instruments FLS 980) using an excitation wavelength of $350 \mathrm{~nm}$. Photoelectrochemical analysis (photocurrent measurements and electrochemical impedance spectroscopy (EIS)) was carried out by the same method described in our previous report [38].

\subsection{Photocatalytic hydrogen production}

A top-irradiation quartz cell connected to a closed glass gas circulation system (CEL-SPH2N, Beijing) was used for photocatalytic hydrogen production. Firstly, the sacrificial agents $\mathrm{Na}_{2} \mathrm{SO}_{3}(0.35 \mathrm{~mol} / \mathrm{L})$ and $\mathrm{Na}_{2} \mathrm{~S} \cdot 9 \mathrm{H}_{2} \mathrm{O}(0.25 \mathrm{~mol} / \mathrm{L})$ were dissolved in $25 \mathrm{~mL}$ of water. Secondly, $10 \mathrm{mg}$ of the prepared photocatalyst was added under stirring (note: no co-catalyst was added), and then, the resultant suspension was completely evacuated. Subsequently, the suspension was irradiated with a xenon arc lamp (225 W, 320-780 nm). The temperature of the whole reaction was maintained at about $6{ }^{\circ} \mathrm{C}$, and the $\mathrm{H}_{2}$ produced was detected with an on-line thermal conductivity detector (TCD) gas chromatograph (GC-9720).

\section{Results and discussion}

\subsection{Crystal structure and morphology}

The XRD patterns of the prepared samples are displayed in Fig. 1. The patterns showed three strong peaks at $31.77^{\circ}$,

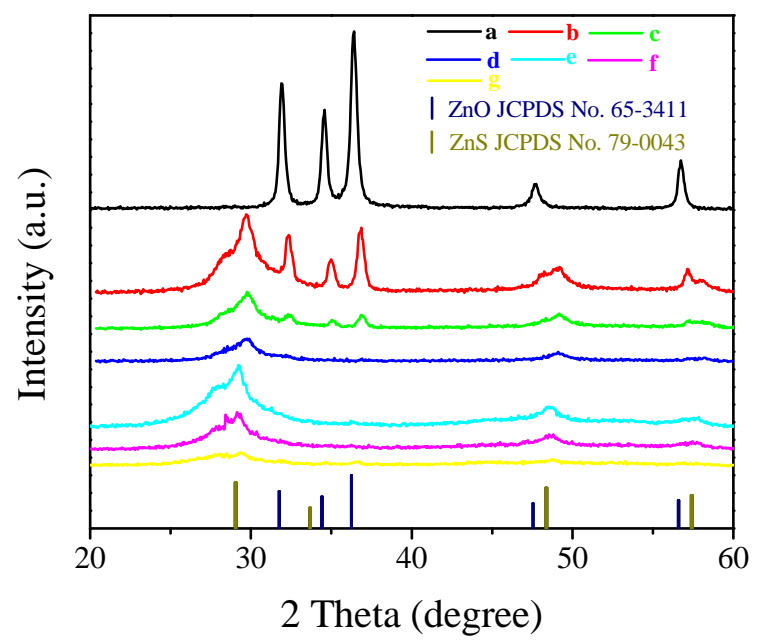

Fig. 1. XRD patterns of the prepared samples: (a) ZnO, (b) ZZ-30, (c) ZZ-35, (d) ZZ-40, (e) CZZ-2, (f) CZZ-4, and (g) CZZ-6. $34.42^{\circ}$, and $36.26^{\circ}$ which were assigned to the (100), (002), and (101) crystal planes of hexagonal wurtzite ZnO (JCPDS No. 65-3411), respectively. Moreover, ZZ-30, ZZ-35, and ZZ-40 showed three new XRD peaks at $29.06^{\circ}, 48.37^{\circ}$, and $57.42^{\circ}$, which were indexed to the (111), (220), and (311) planes of ZnS (JCPDS No.79-0043), respectively, indicating the formation of $\mathrm{ZnS}$ on the surface of $\mathrm{ZnO}$ via in situ sulfidation. Furthermore, as the addition amount of thiourea increased, the $\mathrm{ZnO}$ peak became weaker, while the $\mathrm{ZnS}$ peak became stronger, demonstrating that $\mathrm{ZnO}$ was gradually consumed and converted to $\mathrm{ZnS}$. Besides the characteristic $\mathrm{ZnO}$ and $\mathrm{ZnS}$ diffraction peaks, weak wide diffraction peaks in the range of $24^{\circ}-30^{\circ}$ were observed in the XRD patterns of the CZZ-y samples, which were attributed to the deposited CdS QDs (JCPDS 41-1049) [48].

Figure 2 shows the typical SEM images of the as-prepared nanofibers. As observed in Fig. $2 \mathrm{~A}$ and $2 \mathrm{~B}$, the $\mathrm{PVP} / \mathrm{Zn}\left(\mathrm{CH}_{3} \mathrm{COO}\right)_{2}$ composite fibers with lengths of several micrometers and diameters of 250-300 nm exhibited smooth surfaces. The $\mathrm{ZnO}$ nanofibers (Fig. 2C and 2D) obtained after the heat treatment at $550{ }^{\circ} \mathrm{C}$ in air for $3 \mathrm{~h}$ exhibited lower lengths and diameters: a dozen or even dozens of micrometers and 100-150 nm, respectively, due to the decomposition of PVP. The SEM images of ZZ-35 are shown in Fig. 2E and 2F. Although the 1D nanofiber morphology was maintained during in situ sulfidation, the nanofibers were broken (several micrometers in length), as shown in Fig. 2E. However, after the deposition of CdS QDs, no obvious change in the morphology of the nanofibers was observed (Fig. S1). Notably, the pristine CdS sample exhibited nanoparticle morphology (Fig. S2).

Figure 3 shows the TEM and HRTEM images of CZZ-4. CZZ-4 exhibited the original 1D nanofiber morphology; the diameters of the nanofibers were about $200 \mathrm{~nm}$ (Fig. 3A). The HRTEM image of the sample (Fig. 3B) exhibited lattice fringes separated by distances of $0.31,0.35$, and $0.28 \mathrm{~nm}$ (for clarity, see the magnified images in Fig. 3C), which were assigned to the (111) planes of $\mathrm{ZnS}$, (100) planes of CdS, and (100) planes of $\mathrm{ZnO}$, respectively, demonstrating the successful synthesis of ternary HSs composed of $\mathrm{ZnO}, \mathrm{ZnS}$, and CdS.

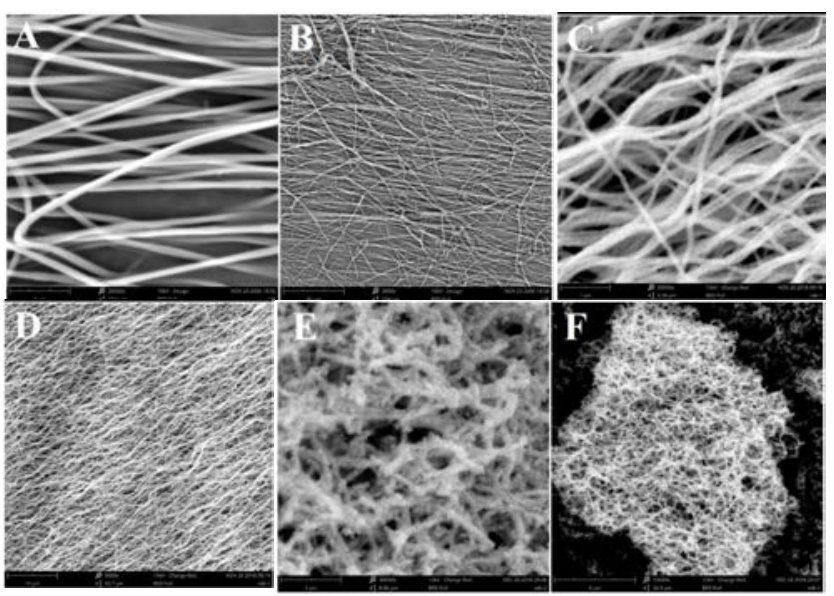

Fig. 2. SEM images of the prepared samples at different magnifications: (A) and (B) PVP/Zn( $\left(\mathrm{CH}_{3} \mathrm{COO}\right)_{2}$ composite fibers before heat treatment, (C) and (D) ZnO nanofibers, and (E) and (F) ZZ-35 nanofibers. 


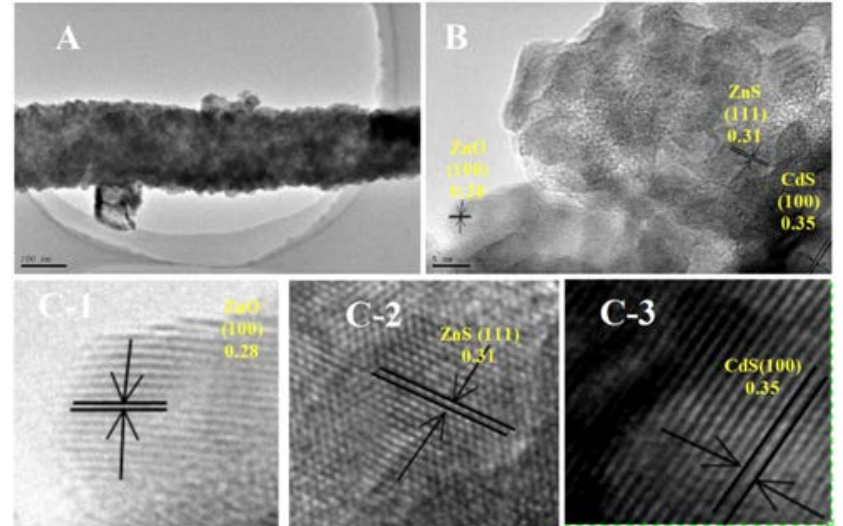

Fig. 3. TEM image of CZZ-4 (A) and HRTEM images of CZZ-4 (B), ZnO (C-1), ZnS (C-2), and CdS (C-3).

Figure 4 shows the EDX mapping images of CZZ-4. As observed, $\mathrm{Zn}$ and $\mathrm{Cd}$ were uniformly distributed at the nanoscale. The density of the yellow dots (i.e., Cd concentration; see Fig. 4B) was significantly lower than that of the red dots (i.e., $\mathrm{Zn}$ concentration; see Fig. 4C), demonstrating that CdS QDs in small amounts were uniformly distributed on the $\mathrm{ZnO} / \mathrm{ZnS}$ matrix. The amount of CdS QDs in CZZ-4 was determined with an EDX system integrated into an SEM instrument (Fig. S3). As shown in Table S1, the amount of CdS QDs in CZZ-4 was about 2.34 at.\%.
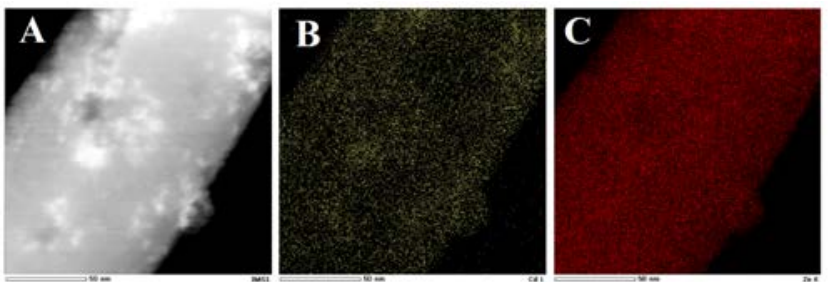

Fig. 4. EDX mapping images of CZZ-4 showing the scanned area (A), and $\mathrm{Cd}(\mathrm{B})$ and $\mathrm{Zn}(\mathrm{C})$ distribution.

\subsection{Chemical compositions and surface chemical states}

The chemical compositions and surface chemical states of CZZ-4 were further studied by XPS. The Cd $3 d$ XPS profile (Fig. $5 \mathrm{~A})$ exhibited two strong peaks at binding energies of 404.9 and $411.7 \mathrm{eV}$, which were assigned to the $\mathrm{Cd} 3 d_{5 / 2}$ and $\mathrm{Cd} 3 d_{3 / 2}$ core levels, respectively [49-51]. The $01 s$ spectrum was deconvoluted into two peaks at 530.8 and $532.1 \mathrm{eV}$ (Fig. 5B), corresponding to the lattice oxygen species (lower binding energy) and chemisorbed oxygen species (higher binding energy), respectively [52,53]. The S $2 p$ XPS profile (Fig. 5C) exhibited two peaks centered at 161.4 and $162.6 \mathrm{eV}$, corresponding to the $\mathrm{S}$ $2 p_{1 / 2}$ and $S 2 p_{3 / 2}$ electronic states, respectively [54-56]. The high-resolution Zn $2 p$ XPS profile exhibited two peaks centered at 1021.9 and $1044.9 \mathrm{eV}$ (Fig. 5D), which were assigned to $\mathrm{Zn}$ $2 p_{3 / 2}$ and $\mathrm{Zn} 2 p_{1 / 2}$, respectively, suggesting that $\mathrm{Zn}$ existed in
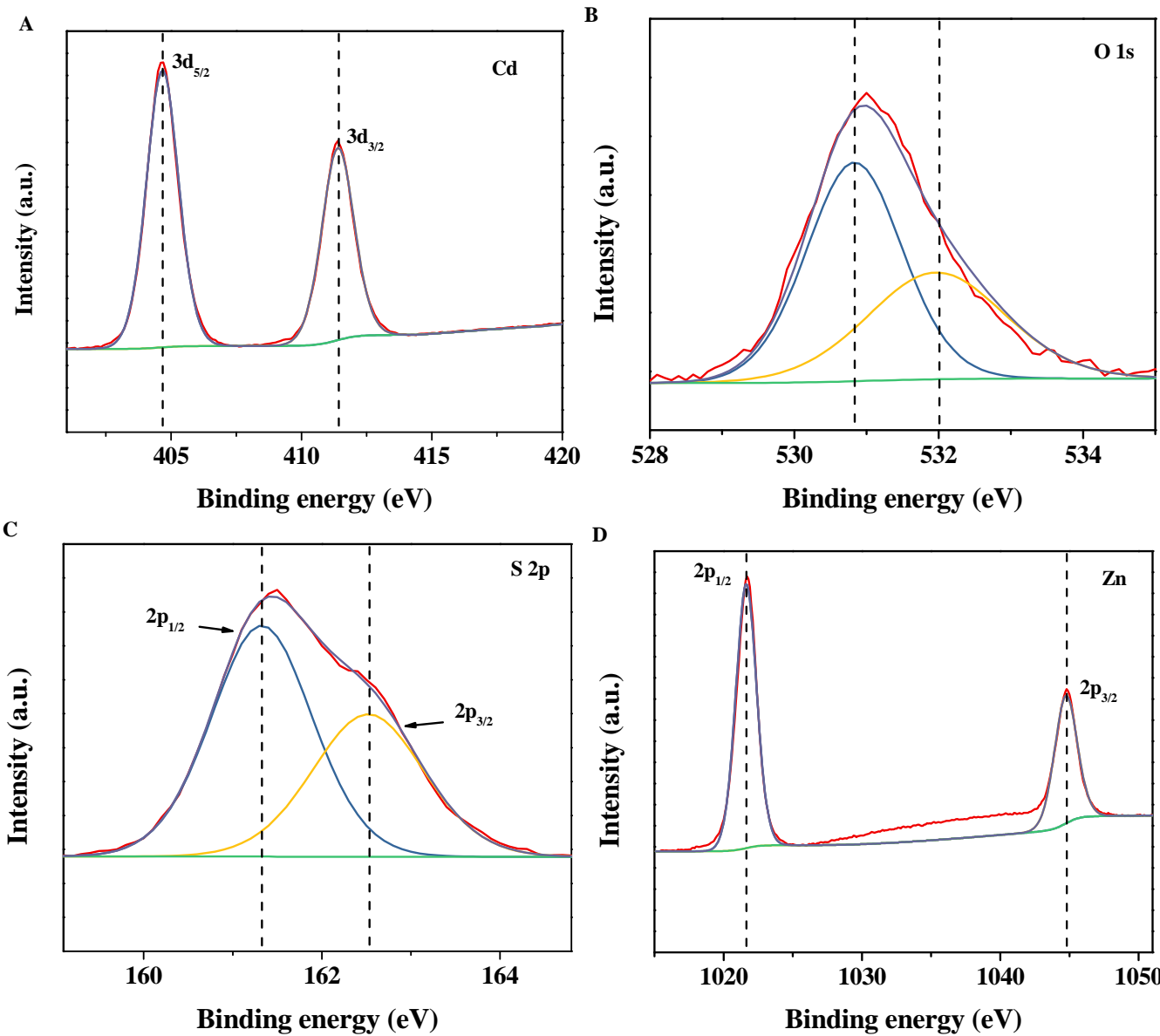

Fig. 5. High-resolution XPS data for CZZ-4: Cd $3 d$ (A), $01 s$ (B), S $2 p(\mathrm{C})$, and Zn $2 p$ (D) spectra. 

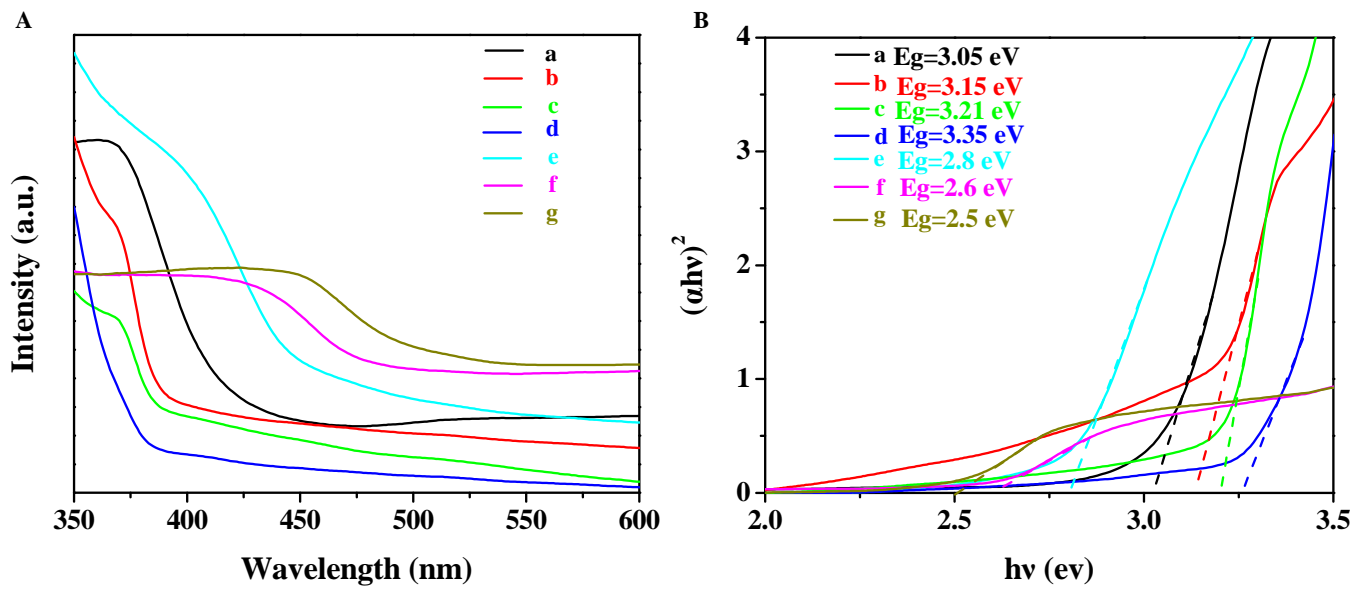

Fig. 6. UV-vis absorption spectra (A) and Tauc plots $\left[(F(R) h v)^{2}\right.$ versus photon energy $\left.(h v)\right]$ (B) of all samples: (a) ZnO, (b) ZZ-30, (c) ZZ-35, (d) ZZ-40, (e) CZZ-2, (f) CZZ-4, and (g) CZZ-6.

the oxidation state of $\mathrm{Zn}^{2+}[31,57]$.

\subsection{Optical property}

Fig. 6A shows the UV-vis absorption spectra of all samples. The $\mathrm{ZnO}$ sample exhibited strong absorption at wavelengths lower than $400 \mathrm{~nm}$ because of its wide bandgap (3.05 eV) [58]. The optical absorption band edge of ZZ- $x$ was blue shifted compared to that of $\mathrm{ZnO}$ and the extent of blue shift gradually increased with increasing vulcanization degree, which can be attributed to the transformation of more $\mathrm{ZnO}$ into $\mathrm{ZnS}$ and the larger bandgap of $\mathrm{ZnS}$ (3.68 eV) compared to that of $\mathrm{ZnO}$ (3.2 $\mathrm{eV}$ ). In contrast, the optical absorption band edge of CZZ-y was red shifted and the extent of red shift gradually increased with the increasing number of CdS QD deposition cycles, which can be attributed to the deposition of more CdS QDs on ZZ-35 and the smaller bandgap of CdS (2.4 eV) compared to those of $\mathrm{ZnO}$ and $\mathrm{ZnS}$ [59]. Fig. 6B shows the Tauc plots of all samples, from which their optical band gap $\left(E_{\mathrm{g}}\right)$ values were determined. $E_{\mathrm{g}}$ was calculated using the equation $\alpha(h v)=A\left(h v-E_{\mathrm{g}}\right)^{1 / 2}$, where $\alpha, v, E_{\mathrm{g}}$, and $A$ are the absorption coefficient, light frequency, band gap energy, and a constant, respectively $[60,61]$. The es- timated $E_{\mathrm{g}}$ values are presented in Fig. 6B.

\subsection{Photocatalytic performance}

Photocatalytic analysis of the samples was carried out in an aqueous solution without additional co-catalysts, such as $\mathrm{Pt}$ and $\mathrm{Au}$, under simulated solar irradiation (320-780 nm). As shown in Fig. 7A, the pristine $\mathrm{ZnO}$ sample exhibited the lowest hydrogen evolution rate $\left(0.55 \mathrm{mmol} \mathrm{h}^{-1} \mathrm{~g}^{-1}\right)$. The samples obtained after sulfidation: ZZ-30, ZZ-35, and ZZ-40 exhibited enhanced photocatalytic performances with $\mathrm{H}_{2}$ evolution rates of 17.86, 22.57, and $17.83 \mathrm{mmol} \mathrm{h}^{-1} \mathrm{~g}^{-1}$, respectively, due to the presence of $\mathrm{ZnS} / \mathrm{ZnO}$ binary HSs, which facilitated the separation and transfer of photogenerated charge carriers. Moreover, the samples obtained after the deposition of CdS QDs on ZZ-35: CZZ-2, CZZ-4, and CZZ- 6 exhibited further enhanced photocatalytic $\mathrm{H}_{2}$ evolution rates: $42.00,51.45$, and $40.08 \mathrm{mmol} \mathrm{h}^{-1}$ $\mathrm{g}^{-1}$, respectively, owing to the presence of CdS/ZnS/ZnO ternary HSs. Among them, CZZ-4 exhibited the highest $\mathrm{H}_{2}$ evolution rate of $51.45 \mathrm{mmol} \mathrm{h}^{-1} \mathrm{~g}^{-1}$, which was 2.28 times higher than that of ZZ-35 (22.57 $\left.\mathrm{mmol} \mathrm{h}^{-1} \mathrm{~g}^{-1}\right)$, indicating that the photocatalytic $\mathrm{H}_{2}$ production performance of ternary HSs
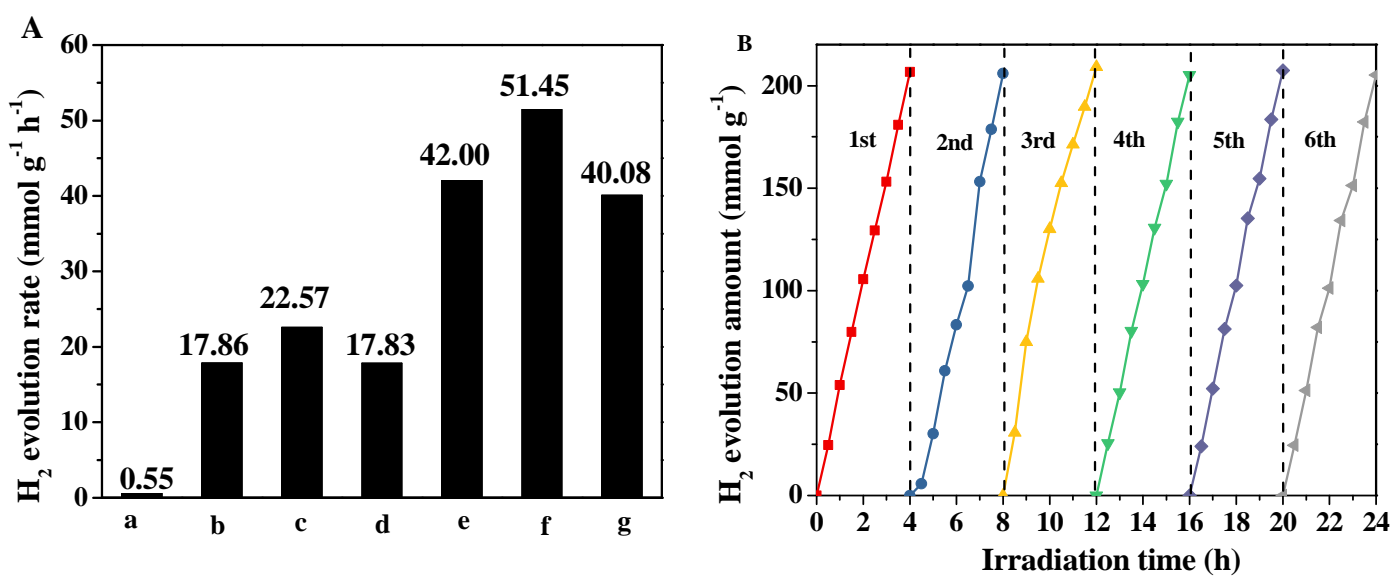

Fig. 7. (A) Photocatalytic $\mathrm{H}_{2}$ production rates for various samples (10 mg): (a) ZnO, (b) ZZ-30, (c) ZZ-35, (d) ZZ-40, (e) CZZ-2, (f) CZZ-4, and (g) CZZ-6; (B) Cyclic runs of photocatalytic $\mathrm{H}_{2}$ production over CZZ-4. 


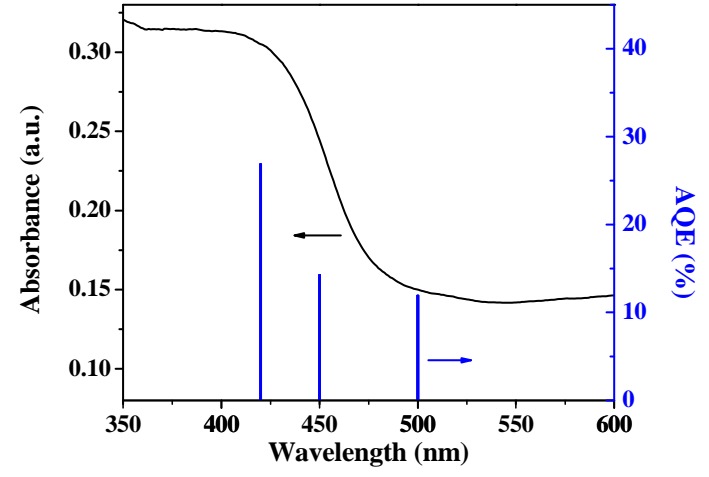

Fig. 8. UV-vis absorption spectrum and AQE values for CZZ-4.

(CdS/ZnS/ZnO) was better than that of binary HSs (ZnS/ZnO). Furthermore, the photocatalytic $\mathrm{H}_{2}$ evolution rate measured over the CZZ-4 sample under visible light irradiation (420-780 $\mathrm{nm}$; a $420 \mathrm{~nm}$ filter was used to filter out the UV light) was $30.56 \mathrm{mmol} \mathrm{h}^{-1} \mathrm{~g}^{-1}$ (Fig. S4). In addition, the $\mathrm{H}_{2}$ evolution rate for CZZ-4 (1D nanofibers) in the presence of a Pt co-catalyst was $118.62 \mathrm{mmol} \mathrm{h}^{-1} \mathrm{~g}^{-1}$ and that for 2D CZZ nanosheets without any co-catalyst was $9.98 \mathrm{mmol} \mathrm{h}^{-1} \mathrm{~g}^{-1}$ (Fig. S5). Notably, under the same conditions, P25 exhibited a photocatalytic $\mathrm{H}_{2}$ evolution rate of $9.8 \mu \mathrm{mol} \mathrm{g}^{-1} \mathrm{~h}^{-1}$, which was significantly lower than that exhibited by CZZ-4.

Moreover, the durability and stability of the optimized CZZ-4 sample were determined by six consecutive processes under the same conditions (the photocatalyst was recovered by centrifugation and redispersed in deionized water with a sacrificial agent after each run). As shown in Fig. 7B, the $\mathrm{H}_{2}$ production remained stable for six cycles (total time: $24 \mathrm{~h}$ ), without significant decline, indicating the good durability and stability of CZZ-4.

The apparent quantum efficiency (AQE) is regarded as an important parameter in the determination of the activity of a photocatalyst; it reflects the conversion efficiency of solar energy into chemical energy during the photocatalytic process. To measure the AQE for CZZ-4, different bandpass filters (at 420, 450 , and $500 \pm 10 \mathrm{~nm}$ ) were used. The method used for the calculation of $A Q E$ is described in the supporting information. As displayed in Fig. 8, CZZ-4 exhibited the highest AQE $(26.88 \%)$ at $420 \mathrm{~nm}$, without any co-catalyst. The AQE values at 450 and $500 \mathrm{~nm}$ were $14.26 \%$ and $11.42 \%$, respectively.

\subsection{Separation and transfer efficiency of charge carriers}

To investigate the photoinduced electron-hole transport mechanism, PL, transient photocurrent response, and EIS measurements were performed. Fig. 9A presents the PL spectra of $\mathrm{ZnO}, \mathrm{ZZ}-35$, and CZZ-4 at an excitation wavelength of 270 $\mathrm{nm}$; the PL spectra of other samples are shown in Fig. S6. ZnO exhibited the highest PL intensity, which was attributed to the fast recombination of photogenerated electrons and holes. ZZ-35 exhibited a lower PL intensity, indicating that the recombination of photoinduced charge carriers was reduced, which was attributed to enhanced separation efficiency of electron-hole pairs in the binary HSs. The PL intensity of CZZ-4 was lower than those of the other two, indicating that the separation efficiency of photogenerated electrons and holes of the ternary HSs was significantly improved [62]. A comparison of Figs. 7A and 9A indicates that the PL intensity is inversely proportional to the hydrogen evolution rate. The higher the PL intensity, the lower is the hydrogen evolution rate, demonstrating that the separation efficiency of photogenerated electron-hole pairs is very critical to the improvement of the hydrogen production efficiency.

The transient photocurrent density versus time curves for the ZnO, CdS, ZZ-35, and CZZ-4 samples under simulated solar light $(320-780 \mathrm{~nm})$ irradiation are presented in Fig. 9B. The photocurrent responses for the other samples are shown in Fig. S7. As shown in Fig. 9B, the samples exhibited steady and reproducible photocurrent responses during repeated on/off illumination cycles. Compared with $\mathrm{ZnO}$, CdS, and ZZ-35, CZZ-4 exhibited a significantly improved photocurrent response, demonstrating the most efficient separation and transfer of photogenerated charge carriers. In addition, the EIS Nyquist plots confirmed the efficient separation and transfer of charge carriers in CZZ-4 (Fig. 9C), which exhibited the smallest radius, indicating that the transfer resistance of charge carriers in the ternary HSs was significantly reduced. The EIS Nyquist plots for other samples are shown in Fig. S3.

On the basis of the above experimental results, we proposed a mechanism for photocatalytic $\mathrm{H}_{2}$ evolution over the prepared CZZ ternary HSs. As shown in Scheme 2, the excitation of all three semiconductors ( $\mathrm{ZnO}, \mathrm{ZnS}, \mathrm{CdS}$ ) under simulated sunlight (320-780 nm) irradiation causes the generation of electrons and holes (the energy levels of $\mathrm{ZnO}, \mathrm{ZnS}$, and $\mathrm{CdS}$, as well as the
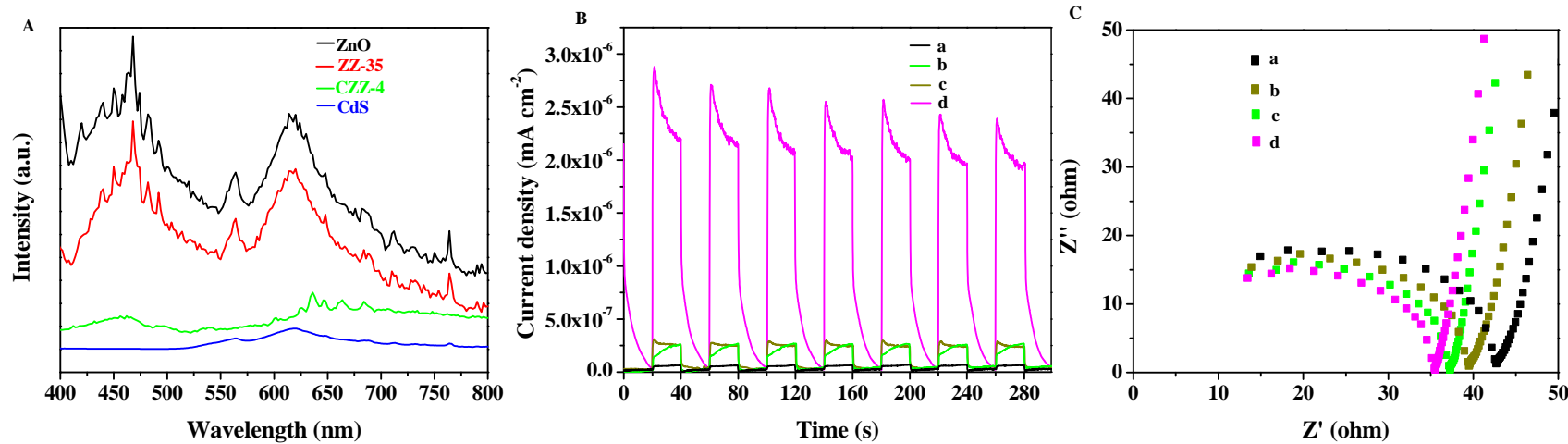

Fig. 9. (A) PL spectra of ZnO, ZZ-35, CdS, and CZZ-4, Photocurrent responses (B) and EIS profiles (C) of ZnO (a), CdS (b), ZZ-35 (c), and CZZ-4 (d). 


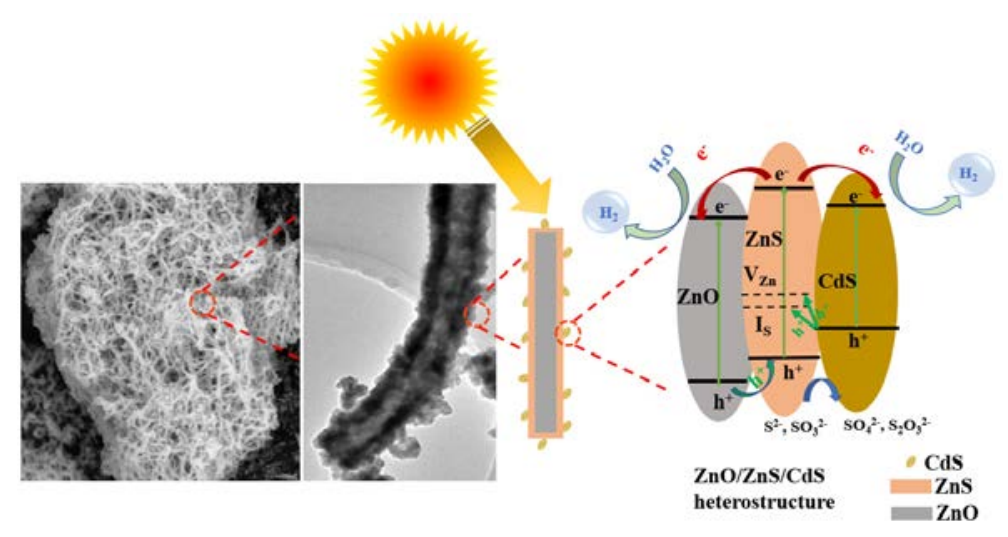

Scheme 2. Proposed photocatalytic $\mathrm{H}_{2}$ evolution mechanism for the CZZ ternary HS.

$\cdot \mathrm{OH} / \mathrm{H}_{2} \mathrm{O}$ and $\mathrm{H}^{+} / \mathrm{H}_{2}$ redox potentials are displayed in Scheme $\mathrm{S} 1)$. The conduction band (CB) position of $\mathrm{ZnS}$ is more negative than those of $\mathrm{ZnO}$ and $\mathrm{CdS}$; therefore, the photogenerated electrons in the $\mathrm{CB}$ of $\mathrm{ZnS}$ will be transferred to the $\mathrm{CBs}$ of $\mathrm{ZnO}$ and $\mathrm{CdS}$, which will then reduce $\mathrm{H}^{+}$to $\mathrm{H}_{2}$. Meanwhile, the photogenerated holes produced in the valence band (VB) of $\mathrm{ZnO}$ will be transferred to the VB of $\mathrm{ZnS}$, which will then react with the sacrificial agents. Moreover, the interface between $\mathrm{ZnS}$ and $\mathrm{CdS}$ induce the transfer of photogenerated holes in the VB of CdS to zinc vacancies $\left(V_{\mathrm{Zn}}\right)$ and interstitial sulfur $\left(I_{\mathrm{S}}\right)$ sites of $\mathrm{ZnS}$ [44,63].

Compared to the CZZ ternary HSs with nanosheet morphology prepared in our previous study [32], the CZZ ternary HSs with nanofiber morphology prepared in the current work exhibited a significantly higher photocatalytic $\mathrm{H}_{2}$ evolution performance. This could be attributed to the following factors. A 2D nanosheet can be regarded as a parallel stack of several 1D nanofibers. Therefore, the geometric size of a nanofiber is considerably smaller than that of a nanosheet. Accordingly, the transfer distance of photogenerated charge carriers from the inside to the surface will be significantly lower, resulting in effective inhibition of recombination of photogenerated electrons and holes and improved photocatalytic hydrogen production efficiency.

\section{Conclusions}

In summary, new ternary CdS/ZnS/ZnO HS nanofibers were successfully prepared by a series of processes: electrospinning $\mathrm{ZnO}$ nanofibers, sulfurizing $\mathrm{ZnO}$ in situ to form $\mathrm{ZnS} / \mathrm{ZnO} \mathrm{HSs}$, and depositing CdS QDs in situ on ZnS/ZnO HSs. The resultant $\mathrm{CdS} / \mathrm{ZnS} / \mathrm{ZnO}$ nanofibers exhibited a hydrogen evolution rate of $51.45 \mathrm{mmol} \mathrm{h}^{-1} \mathrm{~g}^{-1}$ without any co-catalyst, which was significantly higher than that of $\mathrm{CdS} / \mathrm{ZnS} / \mathrm{ZnO}$ nanosheets in the presence of a Pt co-catalyst $\left(27.25 \mathrm{mmol} \mathrm{h}^{-1} \mathrm{~g}^{-1}\right)$ prepared by the same sulfurization and deposition procedures. The enhanced photocatalytic $\mathrm{H}_{2}$ evolution could be attributed to the considerably smaller sizes of 1D nanofibers compared to those of 2D nanosheets, resulting in effectively suppressed recombination of photogenerated charge carriers and promotion of photocatalytic hydrogen production performance. This work indicates that the photocatalytic performance could be improved by reducing the geometric size of the photocatalyst.

\section{Acknowledgments}

TEM and SEM were carried out at Jia-Lab for Interface and Atomic Structure of Xi'an Jiaotong University. EDX mapping and XPS were carried out at Analysis and Test Center of Xi'an Jiaotong University. We thank Hu Nan, Yanzhu Dai, Jiao Li, and Jiamei Liu for their help in using TEM, SEM, EDS mapping and XPS analyses, respectively.

\section{References}

[1] K. Yang, X. Li, C. Yu, D. Zeng, F. Chen, K. Zhang, W. Huang, H. Ji, Chin. J. Catal., 2019, 40, 796-818.

[2] F.-X. Wang, X.-H. Yi, C.-C. Wang, J.-G. Deng, Chin. J. Catal., 2017, 38, 2141-2149.

[3] X. Li, J. Xiong, Y. Xu, Z. Feng, J. Huang, Chin. J. Catal., 2019, 40, 424-433.

[4] Y. X. Li, H. Fu, P. Wang, C. Zhao, W. Liu, C.-C. Wang, Environ. Pollut,, 2019, 113417.

[5] C.-C. Wang, X.-H. Yi, P. Wang, Appl. Catal. B-Environ., 2019, 247, $24-48$.

[6] C. Yu, F. Chen, D. Zeng, Y. Xie, W. Zhou, Z. Liu, L. Wei, K. Yang, D. Li, Nanoscale, 2016, 11, 7720-7733.

[7] F. Mei, Z. Li, K. Dai, J. Zhang, C. Liang, Chin. J. Catal., 2020 41, $41-49$.

[8] A. Fujishima, K. Honda, Nature, 1972, 238, 37-38.

[9] J. Li, X. Gao, B. Liu, Q. Feng, X. B. Li, M. Y. Huang, Z. Liu, J. Zhang, C. H. Tung, L. Z. Wu, J. Am. Chem. Soc., 2016, 138, 3954-3957.

[10] Z. Zhang, J. Huang, Y. Fang, M. Zhang, K. Liu, B. Dong, Adv. Mater., 2017, 29, 1606688.

[11] G. Zhang, Z. Lan, X. Wang, Angew. Chem. Int. Ed., 2016, 55, 15712-15727.

[12] D. Ruan, S. Kim, M. Fujitsuka, T. Majima, Appl. Catal. B-Environ., 2018, 238, 638-646.

[13] L. Wang, W. Wang, W. Zhang, Y. Chen, W. Cao, H. Shi, M. Cao, Appl. Surf. Sci., 2018, 427, 553-560.

[14] L. Wang, W. Wang, Y. Chen, L. Yao, X. Zhao, H. Shi, M. Cao, Y. Liang, ACS Appl. Mater. Interfaces, 2018, 10, 11652-11662.

[15] H. Tong, S. Ouyang, Y. Bi, N. Umezawa, M. Oshikiri, J. Ye, Adv. Mater., 2012, 24, 229-251. 
[16] N. Wu, Int. J. Hydrogen Energy, 2004, 29, 1601-1605.

[17] Y. Zou, J.-W. Shi, D. Ma, Z. Fan, L. Lu, C. Niu, Chem. Eng. J., 2017, $322,435-444$.

[18] Y. Zou, G. Gao, Z. Wang, J. W. Shi, H. Wang, D. Ma, Z. Fan, X. Chen, Z. Wang, C. Niu, Chem. Commun., 2018, 54, 7191-7194.

[19] J. Wen, J. Xie, X. Chen, X. Li, Appl. Surf. Sci., 2017, 391, 72-123.

[20] M. Wu, J.-M. Yan, X.-W. Zhang, M. Zhao, Appl. Surf. Sci., 2015, 354, 196-200.

[21] J.-W. Shi, Y. Zou, L. Cheng, D. Ma, D. Sun, S. Mao, L. Sun, C. He, Z. Wang, Chem. Eng. J., 2019, 378, 122161.

[22] L. Cheng, S. Xie, Y. Zou, D. Ma, D. Sun, Z. Li, Z. Wang, J.-W. Shi, Int. J. Hydrogen Energy, 2019, 44, 4133-4142.

[23] S. Wang, B. Zhu, M. Liu, L. Zhang, J. Yu, M. Zhou, Appl. Catal. B-Environ., 2019, 243, 19-26.

[24] W. Yu, J. Zhang, T. Peng, Appl. Catal. B-Environ., 2016, 181, 220-227.

[25] Z. Jiang, J. Liu, M. Gao, X. Fan, L. Zhang, J. Zhang, Adv. Mater., 2017, 29.

[26] D. You, B. Pan, F. Jiang, Y. Zhou, W. Su, Appl. Surf. Sci., 2016, 363, 154-160.

[27] S. A. Rawool, M. R. Pai, A. M. Banerjee, A. Arya, R. S. Ningthoujam, R. Tewari, R. Rao, B. Chalke, P. Ayyub, A. K. Tripathi, S. R. Bharadwaj, Appl. Catal. B-Environ., 2018, 221, 443-458.

[28] W. Yu, S. Zhang, J. Chen, P. Xia, M. H. Richter, L. Chen, W. Xu, J. Jin, S. Chen, T. Peng, J. Am. Chem. Soc., 2018, 6, 15668-15674.

[29] S. K. Lakhera, H. Y. Hafeez, P. Veluswamy, V. Ganesh, A. Khan, H. Ikeda, B. Neppolian, Appl. Surf. Sci., 2018, 449, 790-798.

[30] H. B. Ahn, J. Y. Lee, CrystEngComm, 2013, 15, 6709.

[31] X. Wang, G. Liu, G. Q. Lu, H.-M. Cheng, Int. J. Hydrogen Energy, 2010, 35, 8199-8205.

[32] J.-W. Shi, D. Ma, Y. Zou, Z. Fan, J. Shi, L. Cheng, X. Ji, C. Niu, J. Power Sources, 2018, 379, 249-260.

[33] F. Huang, J. Hou, H. Wang, H. Tang, Z. Liu, L. Zhang, Q. Zhang, S. Peng, J. Liu, G. Cao, Nano Energy, 2017, 32, 433-440.

[34] D. Ma, J.-W. Shi, D. Sun, Y. Zou, L. Cheng, C. He, H. Wang, C. Niu, L.
Wang, Appl. Catal. B-Environ., 2019, 244, 748-757.

[35] Y. Zou, D. Ma, D. Sun, S. Mao, C. He, Z. Wang, X. Ji, J.-W. Shi, Appl. Surf. Sci., 2019, 473, 91-101.

[36] Y. Zou, J.-W. Shi, L. Sun, D. Ma, S. Mao, Y. Lv, Y. Cheng, Chem. Eng. J., 2019, 378, 122192.

[37] D. Ma, D. Sun, Y. Zou, S. Mao, Y. Lv, Y. Wang, J. Li, J.W. Shi, J. Colloid Interface Sci., 2019, 549, 179-188.

[38] D. Ma, J.-W. Shi, Y. Zou, Z. Fan, X. Ji, C. Niu, L. Wang, Nano Energy, 2017, 39, 183-191.

[39] C. Yu, F. Chen, D. Zeng, Y. Xie, W. Zhou, Z. Liu, L. Wei, K. Yang, D. Li, Nanoscale, 2019, 11, 7720-7733.

[40] M. A. Mahadik, P. S. Shinde, M. Cho, J. S. Jang, J. Am. Chem. Soc., 2015, 3, 23597-23606.

[41] J. W. Shi, Y. Zou, D. Ma, Z. Fan, L. Cheng, D. Sun, Z. Wang, C. Niu, L. Wang, Nanoscale, 2018, 10, 9292-9303.

[42] Y. Zou, J.-W. Shi, D. Ma, Z. Fan, L. Cheng, D. Sun, Z. Wang, C. Niu, ChemSusChem, 2018, 11, 1187-1197.

[43] D. Ma, J.W. Shi, Y. Zou, Z. Fan, J. Shi, L. Cheng, D. Sun, Z. Wang, C. Niu, Nanoscale, 2018, 10, 7860-7870.

[44] G. Sun, S. Mao, D. Ma, Y. Zou, Y. Lv, Z. Li, C. He, Y. Cheng, J.-W. Shi, J. Mater. Chem. A, 2019, 7, 15278-15287.

[45] C. Gao, B. Xiao, J.-W. Shi, C. He, B. Wang, D. Ma, Y. Cheng, C. Niu, J. Catal., 2019, 380, 55-67.

[46] P. Ardalan, T. P. Brennan, H. Lee, J. R. Bakke, l.-K. Ding, M. D. McGehee, S. F. Bent, ACS Nano, 2011, 5, 1495-1504.

[47] J.-W. Shi, D. Sun, Y. Zou, D. Ma, C. He, X. Ji, C. Niu, Chem. Eng. J., 2019, 364, 11-19.

[48] D. Ma, J. W. Shi, Y. Zou, Z. Fan, X. Ji, C. Niu, ACS Appl. Mater. Interfaces., 2017, 9, 25377-25386.

[49] S. N. Guo, Y. L. Min, J. C. Fan, Q. J. Xu, ACS Appl. Mater. Interfaces, 2016, 8, 2928-2934.

[50] B. Chai, T. Peng, P. Zeng, X. Zhang, Dalton Trans., 2012, 41, 1179-1186.

[51] M. Cao, P. Wang, Y. Ao, C. Wang, J. Hou, J. Qian, Dalton Trans., 2015

\section{Graphical Abstract}

Chin. J. Catal., 2020, 41: 1421-1429 doi: 10.1016/S1872-2067(20)63576-8

$\mathrm{CdS} / \mathrm{ZnS} / \mathrm{ZnO}$ ternary heterostructure nanofibers fabricated by electrospinning for excellent photocatalytic hydrogen evolution without co-catalyst

Diankun Sun, Jian-Wen Shi *, Dandan Ma, Yajun Zou, Guotai Sun, Siman Mao, Lvwei Sun, Yonghong Cheng

Xi'an Jiaotong University

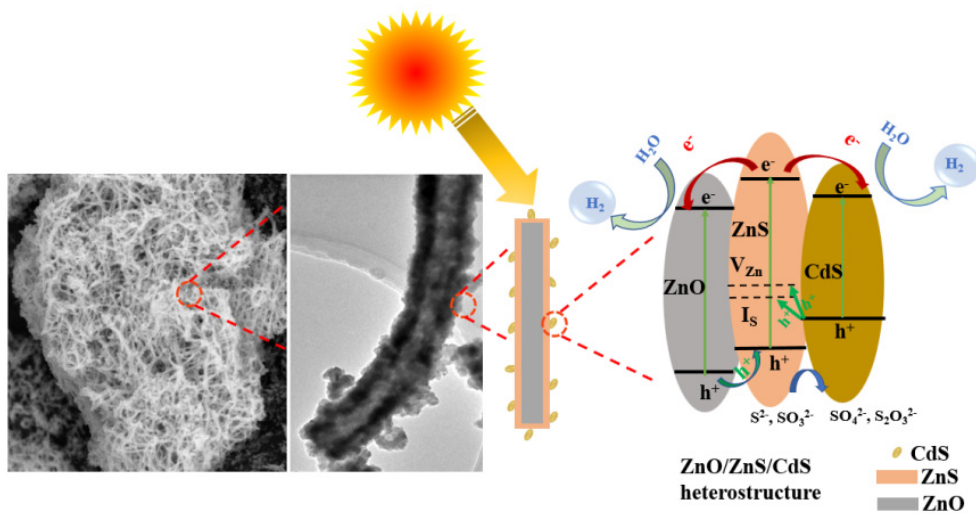

New ternary CdS/ZnS/ZnO heterostructures with one-dimensional (1D) nanofiber morphology are successfully prepared for the first time; these nanofibers exhibit a hydrogen evolution rate of $51.45 \mathrm{mmol} \mathrm{h}^{-1} \mathrm{~g}^{-1}$ without any co-catalyst. 
44, 16372-16382.

[52] F. Xu, Y. Yuan, H. Han, D. Wu, Z. Gao, K. Jiang, CrystEngComm, 2012, 14, 3615.

[53] W. K. Jo, T. Sivakumar Natarajan, ACS Appl. Mater. Interfaces., 2015, 7, 17138-17154.

[54] M. Gopannagari, D. P. Kumar, H. Park, E. H. Kim, P. Bhavani, D. A. Reddy, T. K. Kim, Appl. Catal. B-Environ., 2018, 236, 294-303.

[55] D. A. Reddy, H. Park, R. Ma, D. P. Kumar, M. Lim, T. K. Kim, ChemSusChem, 2017, 10, 1563-1570.

[56] J. Fang, J. Gu, Q. Liu, W. Zhang, H. Su, D. Zhang, ACS Appl. Mater. Interfaces, 2018, 10, 19649-19655.

[57] Z. Zhou, F. Han, L. Guo, O. V. Prezhdo, Phys. Chem. Chem. Phys.,
2016, 18, 16862-16869.

[58] C. Wu, L. Shen, H. Yu, Q. Huang, Y. C. Zhang, Mater. Res. Bull., 2011, 46, 1107-1112.

[59] K.-H. Cho, Y.-M. Sung, Nano Energy, 2017, 36, 176-185.

[60] X. Li, Z. Zhang, L. Chen, Z. Liu, J. Cheng, W. Ni, E. Xie, B. Wang, J. Power Sources, 2014, 269, 866-872.

[61] J. Li, J. Cao, X. Zhang, S. Wang, Y. Zheng, J. Pan, C. Li, J. Mater. Sci.-Mater. El., 2015, 27, 1479-1484.

[62] S. Cao, Q. Huang, B. Zhu, J. Yu, J. Power Sources, 2017, 351, 151-159.

[63] Y. P. Xie, Z. B. Yu, G. Liu, X. L. Ma, H.-M. Cheng, Energy Environ. Sci., 2014, 7, 1895-1901.

\title{
静电纺丝法制备的 CdS/ZnS/ZnO三元异质结纳米纤维无助催化剂下的 光催化产氢性能
}

\author{
孙殿坤，石建稳"，马丹丹，邹雅珺，孙国太，毛思鳗，孙吕伟，成永红 \\ 西安交通大学电气工程学院电力设备电气绝缘国家重点实验室, 新型储能与能量转换纳米材料研究中心, 陕西西安710049
}

摘要: 近年来, 由三种半导体组成的三元异质结由于其在促进光生电子和空穴的分离和转移方面的优势而备受关注. 在本 研究中, 我们首先通过静电纺丝技术制备了 $\mathrm{ZnO}$ 纳米纤维, 然后对其进行原位硫化, $\mathrm{ZnO}$ 纳米纤维的表层被硫化成 $\mathrm{ZnS}$, 得 到 $\mathrm{ZnS} / \mathrm{ZnO}$ 二元异质结纳米纤维, 最后采用连续离子层吸附反应法在 $\mathrm{ZnS} / \mathrm{ZnO}$ 纳米纤维上沉积 CdS 量子点, 得到 $\mathrm{CdS} / \mathrm{ZnS} / \mathrm{ZnO}$ (CZZ)三元异质结纳米纤维. 我们对硫化过程中使用的硫化剂(硫脉)的浓度和离子层吸附沉积CdS的次数进 行调节, 以优化CZZ三元异质结纳米纤维的产氢性能, 经优化后的CZZ三元异质结纳米纤维在没有助催化剂的情况下产氢 速率达到 $51.45 \mathrm{mmol} \mathrm{h}^{-1} \mathrm{~g}^{-1}$ (420 nm处的表观量子效率达到 $26.88 \%$ ), 是相同情况下氧化锌纳米纤维的 93.54 倍, $\mathrm{ZnS} / \mathrm{ZnO}$ 二 元异质结纳米纤维的2.28倍. 加入贵金属Pt作助催化剂后, 其产氢速率进一步提高至 $118.62 \mathrm{mmol} \mathrm{h}^{-1} \mathrm{~g}^{-1}$.

为了突出一维纳米纤维对光催化产氢性能的贡献, 我们采用超声辅助水热法制备得到了二维的ZnO纳米页, 然后采用 同样的方法和工艺对其进行硫化, 得到二维的 $\mathrm{ZnS} / \mathrm{ZnO}$ 二元异质结纳米页, 最后采用同样的方法和工艺进行 CdS 量子点的 沉积, 最终得到二维的 $\mathrm{CdS} / \mathrm{ZnS} / \mathrm{ZnO}$ 三元异质结纳米页在没有助催化剂的情况下产氢速率只有 $9.98 \mathrm{mmol} \mathrm{h}^{-1} \mathrm{~g}^{-1}$, 加入贵金 属Pt作助催化剂后其产氢速率仅提高至 $27.25 \mathrm{mmol} \mathrm{h}^{-1} \mathrm{~g}^{-1}$. 这些结果表明, 与二维CZZ纳米页相比, 一维CZZ纳米纤维具有 更高的产氢性能. 其原因可归结为: 二维纳米片可以看作是由很多一维纳米纤维沿着轴线方向密集排列堆积而成的, 因此 与二维纳米片相比, 一维纳米纤维的几何尺寸大大减小, 光生电子和空穴迁移到表面的距离显著缩短, 这样可以有效地抑 制光生电子和空穴的复合, 从而提高了光催化产氢速率.

我们对一维CZZ三元异质结纳米纤维的光催化产氢机理进行了研究, 发现在模拟太阳光(320-780 nm)照射下, 三种半 导体 $(\mathrm{ZnO}, \mathrm{ZnS}$ 和CdS) 都能被激发产生电子和空穴. ZnS的导带位置比ZnO和CdS的导带位置负, 因此ZnS导带上的光生电 子将向 $\mathrm{ZnO}$ 和CdS的导带迁移, 然后被氢离子捕获生成氢气. 同时, $\mathrm{ZnO}$ 价带上产生的光生空穴被转移到ZnS的价带上, 然 后与牺牲剂反应被消耗掉. 对于ZnS与CdS之间的界面, CdS 价带上的光生空穴可以跃迁到 $\mathrm{ZnS}$ 的两个杂质能级 $\left(V_{\mathrm{Zn}}\right.$ 和 $\left.I_{\mathrm{S}}\right)$ 中, 这样有效避免了CdS的光腐蚀, 使CZZ三元异质结呈现出很好的光催化稳定性. 该工作对构建三元异质结促进光生载流子 的分离和迁移具有借鉴意义.

关键词: 光催化; 产氢; 水分解; 静电纺丝; 异质结

收稿日期: 2020-01-18. 接受日期: 2020-02-24. 出版日期: 2020-09-05.

*通讯联系人. 电话/传真: (029)83395372; 电子信箱: jianwen.shi@mail.xjtu.edu.cn 基金来源：国家自然科学基金(21972110); 陕西省自然科学基金(2019JM-154); 电力设备电气绝缘国家重点实验室基金 (EIPE19123).

本文的电子版全文由Elsevier出版社在ScienceDirect上出版(http://www.sciencedirect.com/science/journal/18722067). 